\title{
ОСОБЛИВОСТІ ЕКСПЕРТИЗИ УСТРИЦЬ
}

\author{
Т.С. ЯРОШЕВИЧ
}

Луиякий национальний технический университет

\section{ОСОБЕННОСТИ ЭКСПЕРТИЗИ УСТРИЦ}

\author{
T. YAROSHEVYCH \\ Lutsk National Technical University
}

\section{SPECIAL ASPECTS OF EXPERTISE OF OYSTERS}

\section{https://doi.org/10.36910/6775-2310-5283-2019-12-05}

Метою статті є визначення особливостей та практичних аспектів експертизи двостулкових молюсків - устрищь. аналіз.

Методика. Збір фактичного матеріалу щэодо досліджуваної проблеми та його

Результати. Дослідження, висвітлені у наукових публікаціях украйнських науковців, значимі, але стосуються, в основному, механізмів освоєння біоресурсів моря, технічних та екологічних проблем морського промислу, організації устричного фермерства, чинників, які беруть участь у формуванні тонких смакових властивостей иих двостулкових молюсків. Устриці є делікатесним, дієтичним продуктом високої комериійної вартості й належать до небагатьох видів харчових продуктів, які споживають живцем. Устриці підлягають обов'язковій ветеринарно-санітарній експертизі. Особливістю експертизи устриць мікробіологічний та бактеріологічний види контролю для встановлення їх загальної безпечності. В ході досліджень, у першу чергу, визначають органолептичні показники молюсків, які відображають їх свіжість. Далі виконують дослідження на присутність патогенної мікрофлори, визначають наявність токсинів, проводять бактеріологічні дослідження. Крім тіла молюска, досліджують також рідину, яка заповнює черепашку. Оскільки устриці $\epsilon$ придонними організмами, їх первинна мікрофлора відповідає мікрофлорі морського осаду, мулу й води, отже одночасно з мікробіологічним контролем молюсків проводиться контроль морської води з районів їх вирощування $і$ видобування. 3 причини того, щуо устричний бізнес в Україні знаходиться на стадії початкового розвитку, державного стандарту, який регламентував би вимоги до якості устриць, не розроблено. Оскільки Україна є членом міжнародної організаџії Комісії Кодекс Аліментаріус, за нормативний документ щодо показників якості та безпеки устриць слід використовувати стандарт ичієї організації.

Наукова новизна. В статті відображено результати аналізу якісних показників, які відповідають за безпечність вживання в їжу сирих молюсків. Отримали подальшого розвитку дослідження щзодо надзвичайної важливості мікробіологічних критеріїв якості сирих молюсків при визначенні їх придатності до споживання та безпеки для споживачів. 
Практична значимість. Відображено аспекти проведення експертизи устриць; обтрунтовано необхідність дотримання гігієнічних правил у процесі природнього видобутку, культивування та зберігання двостулкових молюсків; обтрунтовано необхідність гармонізації вітчизняного законодавства з міжнародним стосовно безпеки устриць як біологічно изінного продукту харчування.

Ключові слова: двостулкові молюски, устриці, експертиза, споживна цінність, якicmb.

Постановка проблеми у загальному вигляді та їі зв'язок з важливими науковими та практичними завданнями. Найбільшим виробником устриць у світі є Китай (80\% світового виробництва). Видобувають та культивують устриць також у Кореї, Японії, США, країнах ЄС, Канаді, Австралії, на Далекому Сході РФ. Для переважної більшості українців устриці є незвичним делікатесом, причому не лише через специфіку вживання, але й зважаючи на достатньо високу ціну. Україна імпортує левову частку устриць. Власний устричний бізнес в державі знаходиться на стадії початкового розвитку, тому наукових досліджень щодо споживних властивостей та безпечності устриць, як біологічно цінного продукту харчування, недостатньо. Вони $€$ швидкопсувним харчовим продуктом, причому причиною швидкого псування крім патогенних мікроорганізмів $є$ активна дія власних ферментів молюска. Навіть якісні, свіжі устриці містять певну кількість мікроорганізмів, кількість яких під час зберігання невпинно зростає. У наукових літературних джерелах, що стосуються двостулкових молюсків, здебільшого, йдеться про особливості їх культивування та чинники, які беруть участь у формуванні смакових властивостей молюска. Проте, не приділяється належної уваги аналізу якісних показників двостулкових молюсків, які відповідають за їх безпечність. Зважаючи на зростання обсягів споживання устриць в Україні, питання експертизи устриць залишається дуже актуальним.

Аналіз останніх досліджень, у яких започатковано вирішення проблеми. Чорне море надзвичайно перспективне для культивування гідробіонтів, особливо двостулкових молюсків. Наявність протяжної берегової лінії та теплий клімат створюють сприятливі передумови для розвитку малого морського фермерського бізнесу. За таких умов виникає необхідність переходити від промислу до організації промислового культивування гідробіонтів. Вивченням морського фермерського бізнесу у Чорному морі займалися багато вітчизняних і зарубіжних вчених, у тому числі М.В. Гринжевський, О.М.Багров, В.І. Борейко, В.М.Данилов, Ю.П. Мамонтов, В.О. Мурін, В.І. Холодов, Л.М. Єсіна, Ю.С. Шарило, М.С. Стасишен, В.Н. Туркулов, Л.Н. Чижова, Н.Н. Яркіна та інші. 
Зокрема, у праці [1] автори досліджують вплив умов утримання молюсків на їх споживні властивості. У роботі [2] наведено результати ветеринарно-санітарної експертизи двостулкових молюсків прибережної чорноморської зони Одеської області, згідно з якими м'ясо свіжих мідій та устриць не відповідає державним нормам за змістом МАФАМ і бактерій групи кишкової палички. У праці [3] автори висловлюють обгрунтовану думку про переваги у культивуванні виду устриць Crassostrea Gigas (також відомих як тихоокеанська або японська устриця), які є стійкішими до хвороб. В праці [4] автори розглядають проблеми і перспективи розвитку марикультури двостулкових молюсків у акваторії Чорного моря. У статті [5] обгрунтовано наголошується на необхідності гармонізації українського законодавства 3 вимогами країн $\mathrm{CC}$ : автори зауважують, що основною гарантією безпечності рибних продуктів в Україні $є$ контроль за вмістом радіонуклідів, пестицидів і токсичних речовин, водночас відмічаючи, що допустимі норми показників безпеки містяться у низці документів, частина яких була затверджена ще за часів СРСР і є застарілими та невідповідними сучасному рівню технічного регулювання.

Дослідження, висвітлені у наукових та методичних публікаціях українських дослідників, значимі, але стосуються, в основному, механізмів освоєння біоресурсів моря, технічних та екологічних проблем морського промислу, організації устричного та мідієвого фермерства, чинників, які беруть участь у формуванні тонких смакових властивостей різних гідробіонтів. Проте, в наукових працях не приділяється належної уваги аналізу якісних показників, які відповідають за безпечність вживання сирих молюсків. Отже, зважаючи на зростання обсягів споживання устриць в Україні, питання експертизи якості (ветеринарно-санітарної експертизи) устриць є дуже актуальним.

Метою досліджень $€$ визначення практичних аспектів експертизи двостулкових молюсків - устриць.

Виклад основного матеріалу дослідження з повним обгрунтуванням отриманих наукових результатів. Устриці $\epsilon$ делікатесним, дієтичним продуктом високої комерційної вартості й належать до небагатьох видів харчових продуктів, яких споживають живцем. У країнах, які вирощують їстівних молюсків у промислових обсягах, питання санітарно-гігієнічного контролю під час вирощування та реалізації молюсків постійно знаходиться у центрі уваги санітарних служб. Всесвітня організація охорони здоров'я наголошує на важливості санітарного контролю за дотриманням гігієнічних 
правил у процесі природнього видобутку та культивування двостулкових молюсків як об'єктів аквакультури.

Оскільки устричний бізнес в Україні знаходиться на стадії початкового розвитку, діючого державного стандарту України, який би встановлював вимоги до їх якості, поки не розроблено. Оскільки Україна $є$ членом міжнародної організації Комісії Кодекс Аліментаріус, за нормативні документи щодо показників якості та безпеки устриць використовують стандарти цієї організації [6].

Серед основних задач Національної комісії України по Кодексу Аліментаріус є задача гармонізації вітчизняного законодавства 3 міжнародним сфері безпеки харчової продукції. Оскільки мікробіологічні критерії є одними 3 найважливіших при визначенні придатності молюсків до їжі, в багатьох країнах світу розроблені різні бактеріологічні стандарти чистоти молюсків, більшість з яких, незважаючи на деякі відмінності між собою, базується на визначенні групи бактерій кишкової палички. В Україні діючими є також міжнародні нормативно-технічні документи рибницької галузі, які були прийняті за часів членства нашої держави у Співдружності незалежних держав (стандарти, нормативні акти, інструкції, методичні вказівки тощо).

Двостулкові молюски підлягають обов'язковому ветеринарному огляду i ветеринарно-санітарній експертизі. Екологічна ситуація, що склалася на даний час, вимагає проведення ретельного контролю вмісту в продуктах моря шкідливих речовин екзогенного походження, а також мікроорганізмів i паразитів, небезпечних для здоров'я людини. За результатами ветсанекспертизи і необхідних лабораторних досліджень Держветслужбою видається висновок про можливість використання продукції або в їжу людям, або на корм тваринам. Мікробіологічний та бактеріологічний контроль устриць проводиться бактеріологічними відділами державних лабораторій ветеринарної медицини.

Особливістю експертизи двостулкових молюсків $є$ обов'язковий мікробіологічний та бактеріологічний аспекти досліджень для встановлення їх загальної безпечності для споживачів. Відповідно до вимог законів «Про захист прав споживачів», «Про санітарно-епідеміологічне благополуччя населення», «Про ветеринарію» та інших нормативних актів, розроблені санітарні правила i норми по профілактиці інфекційних i паразитарних хвороб, що передаються через морепродукти людині, а також по недопущенню в їжу недоброякісної, забруднених хімічними та біологічними токсинами продуктів моря. 
Живі, здорові устриці все ж містять певну кількість мікроорганізмів. Під час зберігання продукту кількість мікроорганізмів невпинно зростає. 3 метою встановлення реальної картини мікробіологічного обсімінення, крім тіла молюска для досліджень використовують також рідину, яка заповнює черепашку. В ній міститься від 10 до 800 мікробних клітин в 1 мл [7]. Обсіменіння устриць патогенною мікрофлорою (зокрема, бактеріями роду Salmonella) є наслідком забруднень берегових вод неочищеними стоками. В устрицях сальмонели можуть зберігатися від 6 до 30 діб. $€$ поодинокі повідомлення про виявлення в устрицях бактерій $\mathrm{Cl}$. Botulinum, продукуючих ботулотоксин, а також про те, що споживання устриць спричиняло захворювання інфекційним (вірусним) гепатитом типів А і В. Отже, вилов молюсків, призначених для безпосереднього споживання (у т.ч. живцем), відбувається лише у дозволених, контрольованих з боку санітарних служб промислових зонах. Відповідно до вимог [6], перед реалізацією молюски устриці піддаються особливим методам відбору та очистки під особливим контролем спеціально вповноважених офіційних органів, що мають на це законодавчу владу.

Більшість промислових безхребетних, у т.ч. устриці, - придонні тварини, тому їх первинна мікрофлора відповідає мікрофлорі морського осаду, мулу та води, тому одночасно з мікробіологічним контролем молюсків відбувається контроль морської води з районів вирощування і видобування молюсків. Санітарно-мікробіологічний контроль морської води передбачає визначення загальної кількості мікроорганізмів і БГКП. Відбір проб морської води в районах устричних плантацій проводиться 3 плавзасобів. Відбір морської води 3 поверхні проводиться в стерильний посуд ємністю $500 \mathrm{~cm}^{3}$, яка занурюється на 15 см від поверхні води. Відбір води 3 глибини проводиться простерилізованим пробовідбірником. Відібрана морська вода доставляється в найбільш стислі терміни до лабораторії. Доставка в літню пору проводиться в сумках-холодильниках або спеціально пристосованих термосах з льодом. До проб додається супровідна документація за підписом відповідальної особи, в якій вказується район відбору проби, глибина, температура води, час і дата відбору проби. На даний час в районах вирощування промислових видів молюсків санітарно-мікробіологічний контроль морської води і визначення їі якості проводиться відповідно до [7].

Під час проведення експертизи, у першу чергу, виявляють характер зміни в органолептичних показниках молюсків, тобто в ознаках життєздатності, адже експертні дослідження щодо наявності патогенної 
мікрофлори, бактеріологічні дослідження та дослідження наявності токсинів проводиться на вимогу органів ветеринарно-санітарного нагляду у державних лабораторіях (за епідеміологічними показниками або токсикологічною ситуацією у районі вирощування та видобутку молюсків).

Практично всі морепродукти здатні накопичувати в своїх тканинах ртуть i метилртуть - високотоксичну сполуку, здатну викликати важкі ураження нервової системи. Здатність до накопичення сполук ртуті у різних морепродуктів неоднакова. Риби накопичують більше ртуті, ніж молюски. Крім ртуті, в Україні обов'язковому визначенню підлягають такі хімічні елементи, як миш'як, свинець, кадмій. Періодичність лабораторного контролю на вміст токсикантів, радіоізотопів, потенційно небезпечних для здоров'я людей мікроорганізмів і личинок гельмінтів згідно з [8] вказано у таблиці 1.

Таблиця 1

Санітарні вимоги до молюсків, направлених для реалізації

у живому вигляді

\begin{tabular}{|l|c|c|}
\hline \multicolumn{1}{|c|}{ Показник } & Допустимий рівень & $\begin{array}{c}\text { Періодичність } \\
\text { контролю }\end{array}$ \\
\hline $\begin{array}{l}\text { Загальне бактеріальне } \\
\text { обсіменіння (МАФАнМ) }\end{array}$ & $\begin{array}{c}\text { Не більше } 2 \times 10^{3} \text { в } 1 \text { г } \\
\left(1 \mathrm{~cm}^{3}\right)\end{array}$ & Кожна партія \\
\hline БГКП & Відсутність в 1 г $\left(1 \mathrm{~cm}^{3}\right)$ & Кожна партія \\
\hline Сальмонели & Відсутність в 25 г & Періодично \\
\hline Парагемолітичні вібріони & Відсутність в 25 г & Періодично \\
\hline $\begin{array}{l}\text { Загибель або інші патологічні } \\
\text { зміни при дослідженні на } \\
\text { наявність токсинів }\end{array}$ & Відсутність протягом & П4 год. \\
\hline Ентерококи & Не допускаються в 0,1 г & Періодично \\
\hline
\end{tabular}

Санітарно-мікробіологічний контроль устриць

проводиться бактеріологічними лабораторіями підприємств, господарств i санепідстанціями. Контролюється кожна призначена до реалізації партія молюсків. Партією вважаються устриці одного району і дати вилову або підйому колекторів, що пред'являються одним підприємством до одночасної здачі-приймання і оформлені одним документом, який засвідчує їх якість.

Міждержавний стандарт [9] встановлює вимоги до умов, у яких мають проводитися дослідження з визначення органолептичних та фізико-хімічних показників двостулкових молюсків. Згідно з цим стандартом дослідження проводять у спеціально обладнаному приміщенні, а за його відсутності, за 
згодою сторін, в умовах, що виключають вплив зовнішніх чинників на результати проведених досліджень.

Приміщення, в якому проводять визначення показників, має бути захищене від протягів, сторонніх запахів, шумів і оснащено вентиляцією. Поверхні стін приміщення повинні бути виконані 3 вологонепроникних, неабсорбуючих i нетоксичних матеріалів, які легко піддаються миттю i дезінфекції. Стіни приміщення повинні мати світле забарвлення Рекомендована температура повітря в приміщенні - 18-22 ${ }^{\circ} \mathrm{C}$, відносна вологість повітря - 70-80\%. Освітлення приміщення повинно бути забезпечено природним денним світлом без потрапляння прямих сонячних променів або штучним світлом зі спектром, близьким до природного.

Висновки та перспективи подальших досліджень. Устриці, призначені для харчового використання здебільшого є об’єктом аквакультури. 3 огляду на екологічну ситуацію, молюски підлягають ветеринарному огляду i ветеринарно-санітарній експертизі для встановлення їх загальної безпечності для споживачів. Особливістю експертизи устриць $є$ обов’язковий мікробіологічний, бактеріологічний види контролю, а також встановлення вмісту токсичних елементів та пестицидів. Одночасно з мікробіологічним контролем молюсків відбувається санітарно-мікробіологічний контроль морської води з районів вирощування і видобування молюсків. Гостро стоїть задача гармонізації вітчизняного законодавства 3 міжнародним сфері безпеки устриць як біологічно цінного продукту харчування. У ході подальших досліджень буде проводитися експертиза устриць, які реалізуються через роздрібну торговельну мережу Волинської області.

\section{Список використаних джерел}

1. Французькі устриці [електр. ресурс]. - Режим доступу : https://iz.ru/news/286722.

2. Фодченко I. А. Ветеринарно-санітарна експертиза мідій в Одеській області [електр. pecypc] / I. А. Фодченко, В. В. Касянчук // Зб. наук. праць «Проблеми зооінженерії та ветеринарної медицини» (Ветеринарні науки). - Харків : ХДЗА, 2016. - Вип. 32. - Ч. 2. C. 219 - 230.

3. Шарило Ю.С. Сучасна аквакультура: від теорії до практики : практичний посібник / Ю.С. Шарило, Н.М. Вдовенко, М.О. Федоренко. - К.: Простобук, 2016. - 119 с.

4. Холодов В.И. Акклиматизация тихоокеанской устрицы Crassostrea gigas (Th.) в Черном море / В.И. Холодов, А.В. Пиркова, Л.В. Ладыгина // Рыбн. хозяйство Украины. 2003. - № 2. - С. 6-8.

5. Єсіна Л. М. Аналіз показників безпечності, що встановлені в Україні та країнах ЄС для рибних продуктів / Л. М. Єсіна, Л. М. Горобець // Основные результаты комплексных исследований в Азово-Черноморском бассейне и Мировом океане. 2011. - № 49. - С. 147 - 157. 
6. Моллюски двустворчатые живые и сырые. Codex Stan 292-2008 [електр. pecypc]. - Режим доступу: http://www.proagro.com.ua/ reference/ standard /fish/15234.html.

7. Горшкова О.Г. Санітарно-мікробіологічні і вірусологічні дослідження морської води у рекреаційних зонах Чорноморського узбережжя / О.Г. Горшкова, О.В. Волювач, О.В. Молодіт // Матер. XIII межд. науч.-практ. конф. «Новината за напреднали наука 2017»,Volume 9. - София: Бялград-БГ, 2017. - С. 13 - 15.

8. Метод. указания по санитарно-микробиол. контролю черноморских мидий и устриц [електрон. ресурс]. - Режим доступу : http:// metodicheskie-ukazanija-po-sanitarnomikrobiologicheskomu-kontrolyu-chernomorskih-midij-i-html.

9. Рыба, нерыбные объекты и продукция из них. Методы определения органолептических и физических показателей : ГОСТ 7631-2008. - [Дата введ. 2009-0701]. - М. : Госстандарт СНД, 2008. - 18 с.

Целью статьи является определение практических аспектов экспертизы двустворчатых моллюсков - устриц.

Методика. Сбор фактического материала по исследуемой проблеме и анализ информации

Результаты. Исследования, отображенные в научных публикациях украинских ученых, значимые, но касаются, в основном, механизмов освоения биоресурсов моря, технических и экологических проблем морского промысла, организачии устричного фермерства, факторов, которые участвуют в формировании тонких вкусовых свойств моллюсков. Устрииь являются деликатесным, диетическим продуктом высокой коммерческой стоимости и относятся к одному из немногих видов пищевых продуктов, разрешенных к употреблению без тепловой обработки. Устрииь, безусловно, относятся к скоропортящимся пищевым продуктам. Живые, здоровые моллюски всегда содержат определенное количество микроорганизмов, численность которых во время хранения постоянно увеличивается. Причиной быстрой порчи, кроме патогенных микроорганизмов является активность собственных ферментов моллюска. Устрицы подлежат ветеринарно-санитарной экспертизе. Особенностью экспертизы устриц есть обязательный микробиологический и бактериологический виды контроля для установления их общей безопасности. В ходе исследований, в первую очередь, определяют органолептические показатели моллюсков, которые отображают их свежесть. Далее выполняют исследования на присутствие патогенной микрофлоры, определяют наличие токсинов, проводят бактериологические исследования. Кроме тела моллюска, исследуют также жидкость, которая заполняет раковину. Поскольку устрииы являются придонныли животными организмами, их микрофлора соответствует микрофлоре морского дна и воды, по этой причине одновременно с микробиологическим контролем моллюсков проводят контроль качества морской воды из районов их вырашивания $и$ добычи. В виду того, что устричный бизнес в Украине находится на начальной стадии развития, государственного стандарта Украины, который устанавливал бы требования к качеству устрии не разработано. Поскольку Украина является членом комиссии Кодекс Алиментариус, нормативным документом, регламентирующим показатели качества и безопасности устрии, служит стандарт этой международной организации.

Научная новизна. В статье отражены результаты анализа качественных показателей, которые отвечают за безопасность употребления в пищу сырых моллюсков. Получили дальнейтего развития исследования относительно неоспоримой важности микробиологических критериев качества сырых моллюсков при определении их безопасности для потребителей. 
Практическая значимость. Отражено аспекты проведения экспертизы устриц; обоснована необходимость соблюдения гигиенических правил в проиессе естественной добычи, культивирования и хранения двустворчатых моллюсков; обоснована необходимость гармонизации отечественного законодательства с международным относительно безопасности устрии как биологически ценного продукта питания.

Ключевые слова: двустворчатые моллюски, устрицы, экспертиза, потребительская иенность, качество

Purpose of the paper is to determine the expertise practical aspects of bivalve mollusks oysters.

Methodology. Collection and analysis of actual material concerning the investigated problem.

Findings. Illustrated in the scientific publications of Ukrainian researchers investigations are significant, but they relate mainly to the mechanisms of marine biological resources development, technical and ecological problems of sea fishing, oyster farming organizing, factors that are involved in the formation of their delicate flavor properties. Oysters are a delicious, highvalue dietary product and are among the few types of food eaten alive. They are a perishable food product and the cause of rapid spoilage besides pathogenic microorganisms is in the active action of the mollusk own enzymes. Alive healthy oysters still contain a certain number of microorganisms, the amount of which continuously increases during storage.Oysters are the subject for veterinary and sanitary expertise. The peculiarity of oysters expertise is the mandatory microbiological and bacteriological control to establish their general safety. Organoleptic properties of shellfish are primarily determined during the research. Then researches on the presence of pathogenic microflora are performed, the presence of toxins is determined and bacteriological studies are conducted. In addition to the body of mollusks, the liquid that fills the shell also is examined. Since oysters are benthic animals, their primary microflora corresponds to the microflora of sea sediment, silt and water. Therefore, simultaneously with the microbiological control of mollusks, seawater from the areas of their cultivation and extraction is controlled.

The state standard of Ukraine, which would set the requirements for the quality of oysters, has not been developed, because oysters business in Ukraine is on the initial development stage. Ukraine is a member of the international organization Codex Alimentarius Commission and the standards of this organization are used as normative documents on the quality and safety of oysters.

Originality. The results of the analysis of quality indicators responsible for the safety of eating raw mollusks are described in the article. Research on the extraordinary importance of microbiological criteria of the raw mollusks quality in determining their suitability for consumption and safety for consumers are further developed.

The practical value. Aspects of oysters expertise as a biologically valuable food are shown. The need to comply with hygienic rules in the process of natural extraction, cultivation and storage of bivalve mollusks is justified. An urgent need for harmonization of national legislation on food safety with international legislation is stated.

Keywords: bivalve mollusks, oysters, expertise, consumer value, quality.

Рекомендовано до публікащіі доктором технічних наук, професором Луиького НТУ Байдаковою Л.І. Дата надходження в редакиію 03.01.2019 p. 